\title{
Centrosomal Protein of 76 kDa
}

National Cancer Institute

\section{Source}

National Cancer Institute. Centrosomal Protein of 76 kDa. NCl Thesaurus. Code

C116080.

Centrosomal protein of $76 \mathrm{kDa}(659 \mathrm{aa}, \sim 74 \mathrm{kDa}$ ) is encoded by the human CEP76 gene.

This protein is involved in the regulation of centriole duplication. 